\title{
WestVirginiaUniversity
}

THE RESEARCH REPOSITORY @ WVU

Graduate Theses, Dissertations, and Problem Reports

2000

\section{Heavy metal redistribution in soils using compost as a soil amendment}

Jason Thomas Morrison

West Virginia University

Follow this and additional works at: https://researchrepository.wvu.edu/etd

\section{Recommended Citation}

Morrison, Jason Thomas, "Heavy metal redistribution in soils using compost as a soil amendment" (2000). Graduate Theses, Dissertations, and Problem Reports. 1115.

https://researchrepository.wvu.edu/etd/1115

This Thesis is protected by copyright and/or related rights. It has been brought to you by the The Research Repository @ WVU with permission from the rights-holder(s). You are free to use this Thesis in any way that is permitted by the copyright and related rights legislation that applies to your use. For other uses you must obtain permission from the rights-holder(s) directly, unless additional rights are indicated by a Creative Commons license in the record and/ or on the work itself. This Thesis has been accepted for inclusion in WVU Graduate Theses, Dissertations, and Problem Reports collection by an authorized administrator of The Research Repository @ WVU. For more information, please contact researchrepository@mail.wvu.edu. 
Heavy Metal Redistribution in Soils

Using Compost as a Soil Amendment

\author{
Jason T. Morrison
}

Thesis Submitted to the College of Agriculture, Forestry, and Consumer

Science at West Virginia University in Partial Fulfillment of the

Requirements for the Degree of

\author{
Masters of Science \\ in \\ Agricultural and Environmental Education
}

Robert G. Diener, Ph. D., Chair

Louis McDonald, Jr., Ph. D.

Layle D. Lawrence, Ph. D

Division of Resource Management

Morgantown, West Virginia

2000

Keywords: Phytoremediation, Heavy Metal, Composting 


\title{
Abstract \\ Heavy Metal Redistribution in Soils Using Compost as a Soil Amendment
}

\begin{abstract}
Jason T. Morrison
Organic soil amendments such as compost can reduce the availability of heavy metal contaminated soil. The objectives of this study were 1) to evaluate the efficiency of compost as an soil amendment within heavy metal contaminated soil 2) to determine the hypoaccumulation of heavy metals in the stem, shoot, and root systems of white clover and wheat 3) to identify movement of heavy metals within the soil 3) to evaluate the differences of nodule formation in Trifolim repens. Three volumes of compost were added to a heavy metal contaminated soil (additions of zero, 10, and 40 percent compost, by volume). Zinc, $\mathrm{Cd}$, and $\mathrm{Pb}$ contamination was analyzed in soil fractions and the roots and shoots of wheat (Triticum aestivum) and white clover (Trifolim repens). The increased addition of compost was found to alleviate the toxic effects that heavy metal have on plant health; while redistributing metals to a less available form. An increase of nodule formation and nitrification resulted with the addition of compost to heavy metal contaminated soil.
\end{abstract}




\section{Acknowledgements}

I would like to thank Dr. Louis McDonald for generously providing the use of his lab and aiding in the design and data analysis of my research. To Dr. Robert Diener for providing me with an assistantship and allowing me to investigate research within the

field of remediation. To Dr. Layle Lawrance for sharing his knowledge of thesis format and design. To Joan Wright for assisting in data analysis. I would also like to thank my parents, John and Nancy, and my sister Andrea, and most of all, my future wife, Katie, for their never-ending love and support. 


\section{TABLE OF CONTENTS}

\section{Page}

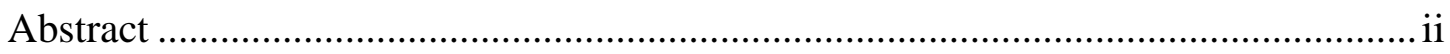

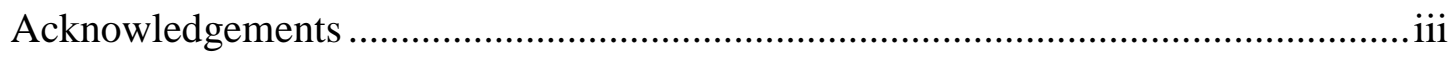

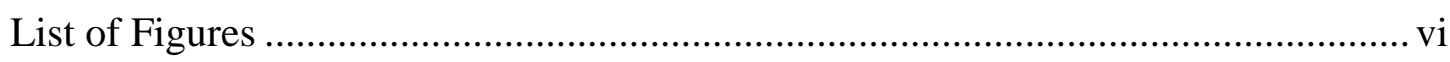

List of Tables................................................................................................. vii

Chapter One

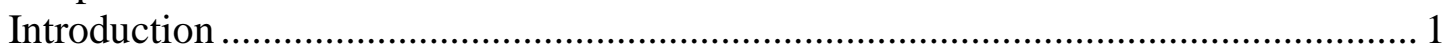

Heavy Metal Contaminated Soil - Site Background ................................................ 2

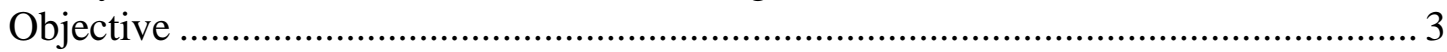

Chapter Two

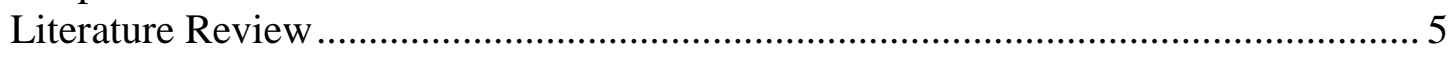

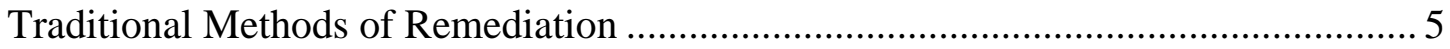

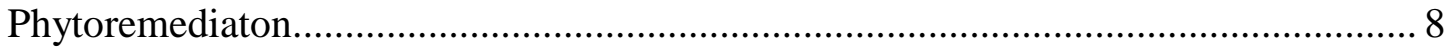

Chapter Three

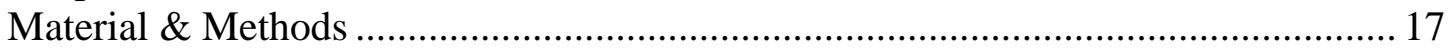

Collection of the Contaminated Soil for this Study ................................................ 17

Preparation of Test Pots for Growth Chamber....................................................... 17

Chapter Four

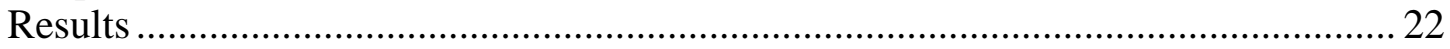

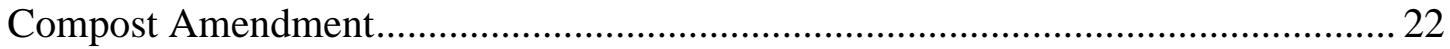

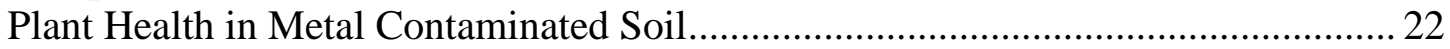

Nodule Formation of White Clover .................................................................. 24

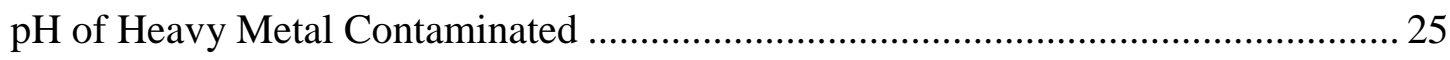

Heavy Metal Up-Take of Wheat and White Clover............................................... 26

Sequential Extraction of Heavy Metal Contaminated Soil ....................................... 29

Chapter Five

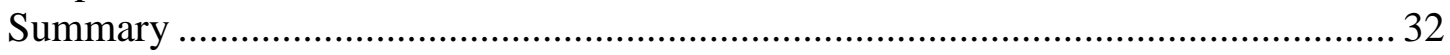

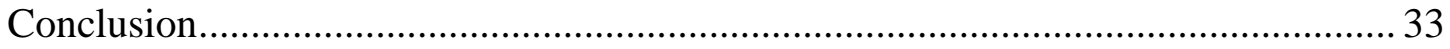

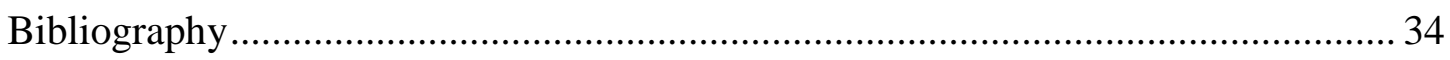

Appendix

Table. 
Appendix B

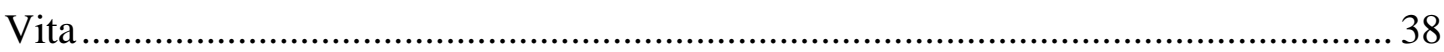




\section{LIST OF FIGURES}

Page

4.1 White clover samples indicated improved health and growth with the increase addition of compost to heavy metal contaminated

soil

4.2 The addition of compost to heavy metal contaminated soil improved root and shoot growth.

4.3 The addition of compost increased nitrogen fixing ability and size of the nodules on white clover roots 25

4.4 High $\mathrm{pH}$ levels were maintained with the addition of compost in metal contaminated soils during the seven-week sample period

4.5 A reduction of $\mathrm{Pb}$ within the plant material of white clover and wheat

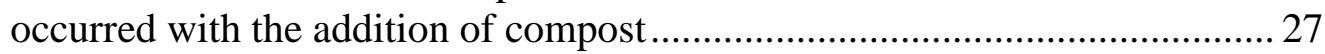

4.6 A reduction of $\mathrm{Zn}$ within the plant material of white clover and wheat occurred with the addition of compost ........................................................... 28

4.7 A reduction of $\mathrm{Cd}$ within the plant material of white clover and wheat occurred with the addition of compost

4.8 The $\mathrm{Zn}$ analysis of the Fe\&Mn fraction showed a decrease in soils from $40 \% \mathrm{CM}$

4.9 Data revealed that $\mathrm{Pb}$ analysis of the carbonate fractions from $10 \%$ CM and 40\% CM white clover and wheat samples were less available than $\mathrm{CO}$ fractions 


\section{LIST OF TABLES}

Page

3.1 Microwave procedures used for soil and plant material ............................. 21

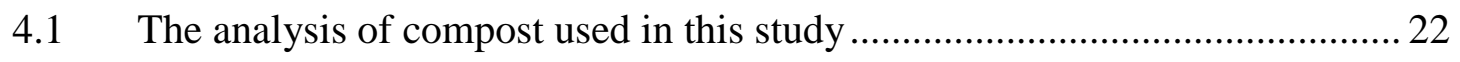

4.2 The increases plant growth efficiency is due to the addition of compost ....... 23

4.3 Wheat has the ability to up-take a higher concentration of heavy metals than white clover ............................................................................ 29 


\section{CHAPTER 1}

\section{Introduction}

Heavy metal contamination of soil poses a major threat to human health and the environment. Toxic heavy metal contamination is prevalent within the surface soils at mining and industrial sites (Huang et al., 1997). Heavy metal pollution is a widespread problem within all industrially developed countries of the world. Past waste disposal practices associated with mining and manufacturing activities have been such that air, soil, and water contamination was common, and as a result there are many metal contaminated sites that pose serious health risks (Roane et al., 1997).

Traditional approaches to remediation of toxic heavy metal contaminated soils are typically expensive, labor intensive, and environmentally inefficient. Available space at hazardous waste disposal sites and growing regulations are rapidly depleting incineration and landfilling processes as remediation options. Land-ban regulations, such as the California List, bans the incineration and disposal of corrosive heavy metals. Landfill disposal costs were between $\$ 25$ - $\$ 60$ per drum in 1983 increased to $\$ 64$ - $\$ 186$ per drum in 1987. Incineration costs of highly toxic substances increased from $\$ 1.50$ - $\$ 3.10$ per gallon in 1983 to $\$ 2.36$ - $\$ 5.02$ in 1987 (Forcella, 1989).

The use of plants to remove hazardous heavy metal contamination from soil is a promising alternative of method soil remedation. Soil amendments can aid in the increase or decrease of the accumulation efficiency of toxic heavy metals within plants. The distribution of metals is significantly influenced by soil $\mathrm{pH}$ and organic matter content (Zang et al. 1997; Tagwira et al. 1993). 
Synthetic and natural soil amendments that increase of the availability of heavy metals enhance plant up-take. Chelates have been used in soils and nutrient solutions to increase the solubility of metal cations in plant growth media and are reported to have significant effects on metal accumulation in plants (Huang et al. 1997). The addition of these amendments release heavy metals, which are bound to soil particles. The release of these metals results in the increase a heavy metal availability, which will additionally increase the risk of heavy metals leeching into the water system.

Organic soil amendments can ameliorate metal toxicity to plants by redistributing metals to less available fractions. Phosphates such as apatite amendments have been successfully used to lower the bioavailabitity and increase the geochemical stability of metal contaminated soil (Laperche et al., 1997). Compost amendments are also used as viable soil amendment within these processes.

Compost and other amendments can be used as a vital tool to restrict the availability of heavy metals in soil. Organic amendments aid in a binding process that occurs if high $\mathrm{pH}$ levels are maintained. Heavy metals bind to the surface of soil particles, resulting in a reduction of availability. The addition of compost to decrease plant accumulation of heavy metals was chosen as an alternative to traditional soil amendments.

\section{Heavy Metal Contaminated Soil - Site Background}

The contaminated soil used for this experiment was collected from a playground owned by the Harrison County Commision in Spelter, West Virginia. The community of Spelter has a significant heavy metal contamination in its soils. The contamination originated from the Zinc Spelter Plant, which is located adjacent to and up-wind of the 
Harrison County owned playground. The Zinc Spelter Plant was operated as a zinc reduction plant from 1911 to 1972. Grasselli Chemical Company constructed and operated the facility in 1910 until it became a division of E. I. DuPont Corporation. It was purchased from the E. I. DuPont Corporation by Matthiessen \& Hegeler Zinc Company in 1950 and operated until 1972.

Approximately 50 acres of the site is covered by waste generated from the zinc reduction process. The waste piles ranges in depth from five to 40 feet. The reduction of zinc was performed in a horizontal and vertical furnace. Zinc sinter (zinc oxide) was ground and mixed with pulverized coal, clay, tar and then briquetted within a furnace. When the zinc reduction was complete the briquettes were removed from the furnace and placed on the waste pile.

Contaminants resulting from the zinc reduction procedure included aluminum, antimony, arsenic, barium beryllium, cadmium, calcium, chromium, cobalt, copper, iron, lead, magnesium, manganese, nickel, potassium, selenium, silver, sodium, vanadium, and zinc. Most of the waste pile consists of intact or partially intact briquettes. Pulverized coal that was not consumed during the reduction process is also present throughout the site (WVDEP, 1997).

\section{$\underline{\text { Objectives }}$}

Research has indicated the efficiency of compost as an effective soil amendment of heavy metal contaminated soil. However, research has not determined the effects of hyperaccumulation, $\mathrm{pH}$, nodule formation, and availability variations within compost mixed with heavy metal contaminated soil. Thus, this study was developed with the following specific objectives: 
1) to evaluate the efficiency of compost as an soil amendment within heavy metal contaminated soil.

2) to determine the hyperaccumulation of Zinc ( $\mathrm{Zn})$, Cadmium (Cd), and Lead $(\mathrm{Pb})$ in the stem, shoot, and root systems of white clover (Trifolim repens) and wheat (Triticum aestivum).

3) to identify movement of $\mathrm{Zn}, \mathrm{Cd}$, and $\mathrm{Pb}$ within the soil.

4) to evaluate the differences of nodule formation in white clover. 


\section{CHAPTER 2}

\section{Literature Review}

\section{Traditional Methods of Remediation}

Several ex-situ and in-situ options exist to remove toxic heavy metal contamination from soil. Ex-situ processes such as incineration and landfilling are traditional methods, which require the soil to be physically removed from the site. Excavation and landfarming are traditional alternatives for the removal of heavy metals. In-situ recovery processes, such as chemical degradation and soil washing are often difficult. Recovery processes include using flocculants to separate the metals from soil, adding resins to absorb the effluents, or the mixing of clay amendments (Watanabe, 1997).

- Excavation

Traditionally, excavation and transport of contaminated soil to an off-site landfill has been a commonly selected alternative, often due to regulatory agency pressure. However, the cost can exceed $\$ 300$ per cubic yard making large disposal efforts very expensive. This alternative also is restrained by the physical limitation of the excavation equipment. Excavations deeper than approximately 20 feet have increased equipment cost, sheeting, and risk of undermining nearby structures, therefore excavation is usually limited to small contaminated soil cleanup projects. Increased contaminated soil volume generally warrants research into treatment alternatives. The physical removal of the soils from the ground through mechanical manipulation may change the physical characteristics of the soils (Shaw et al., 1995). 
- Landfarming

In landfarming applications contaminated soil is removed and treated at an offsite location (ex-situ). The soil is spread over a large area until remediation processes are completed. Several remediation options exist. Chemical additives, soil washing, and phytoremediation methods can be applied to the contaminated soil. Remediators are able to regulate cleaning efforts at a greater efficiency due to the controlled environment present at landfarming sites. However, the cost of landfarming is high and it is a laborintensive process. Contamination of the remediation site is also a drawback to landfarming applications.

- Chemical Degradation

Chemical degradation is a process where oxidizing or reducing agents are injected into the contamination zone to degrade the contaminant into other chemicals. This oxidation-reduction reaction is performed to degrade the chemical to a by-product that has more favorable characteristics, including lower toxicity, increased mobility, volatility, or absorption. The most common chemical degradation is capable of oxidizing many compounds in the following classes: halogenated hydrocarbons, halogenated aromatics, pesticides, and heavy metals (Shaw et al., 1995).

The chemical reactivity of a contaminant, and its mobility within the soil during application of the oxidizing-reducing agent, will be a factor of the ultimate fate of a chemical. The interaction between dissolution and sorption at a site complicates the remedial design and frequently gives reason to eliminate this technology as a remedial alternative. In addition, unfavorable by-products are often the result of chemical degradation. These by-products may have decreased volatility or adsorption 
characteristics, making them more difficult to remove following chemical degradation (Shaw et al., 1995).

- Soil Washing

Soil washing utilizes the solubility of a substance in water to transfer it from the soil matrix into the groundwater. Typically, an underground piping network or aboveground bermed area or pit is constructed spanning the dimensions of the contaminated area. A water flow is maintained through groundwater recovery wells. The groundwater is recovered through groundwater recovery wells. The groundwater is then pumped to the surface and treated. Subsequently, the treated groundwater may be reinjected into the contaminated soil area.

Water was commonly used as the flushing solution. Recently, other agents, such as acids, chelating agents and phosphates, have been used to enhance the flushing rate of a chemical from the soil matter. Soil washing may be described as an accelerated precipitation and percolation process. This description is based on large quantities of water generally required to remove the contaminants from the soil matrix, compared to the low quantities of precipitation rates received in most locations. If a soil washing system is designed properly, the overall length of time for groundwater recovery and treatment can be reduced significantly (Shaw et al., 1995). A major consideration is the capacity of the groundwater recovery system. Measures must be established to verify that the groundwater recovery system will recover all the contaminants that are flushed from the soil. Additionally, the treatment system must be designed to handle the added contaminant loading. 
- Microbial Remediation

Microbial systems are commonly used to remediate domestic waste, and to recover precious metals from ore. Biohydrometalurgy uses microorganisms in the recovery process of precious metals, such as copper and gold. Additional processes include the use of bacteria, algae, fungi, and yeasts to complex or sorb metals. Scott et al.(1988) concluded that the microorganism additions increase metal complexation. A profound issue in metal remediation is that through microbial action, metals can readily be re-mobilized, creating toxicity issues in sites where metals are not completely removed (Roane et al., 1997).

- In-situ Bioremediation

In-situ bioremediation is treatment in place. Good soil permeability is important for bioremediation to work but may also allow the petroleum hydrocarbons to penetrate too deeply. Practical limits are about 20 feet in depth. This is the least expensive and least labor intensive method. This method has a large advantage of not requiring movement of the soil. The disadvantage is that materials are not mixed and agitated to uniformity. Treatment times can range from weeks to years, depending upon contamination levels and depths of contamination. In-situ methods offer only limited assurance that the site has been treated to acceptable levels due to the difficulty in obtaining a representative sample.

\section{$\underline{\text { Phytoremediation }}$}

Phytoremediation is a natural process carried out by plants that are able to live in a contaminated media. Plants are able to either absorb high levels of contaminants within their roots or reduce their availability, essentially rendering them harmless (Watanabe, 
1997). Phytoremedition has been tested on sites contaminated by petroleum products, munitions, radionuclides, abandoned mines, wood treatment, and sewage treatment. Phytoremediation experts say the growth of interest in the field is driven by its relative cost-efficiency compared to standard remediation methods for governmentmandated site cleanup (Watanabe, 1997). In situ remediation of a contaminated site may cost between $\$ 10$ and $\$ 100$ per cubic meter, whereas ex situ remediation may cost as much as $\$ 30$ to $\$ 300$ per cubic meter. In comparison, phytoremediation may cost as little as $\$ 0.05$ per cubic meter (Cunningham, 1997).

The extractions of heavy metals from soils are induced by hyperaccumulating plants. The plants store high levels of toxic heavy metals within their roots, shoots, and leaves. Hyperaccumulating plants must have the ability to accumulate heavy metals, have a high biomass production, and disease and pest resistance in order to flourish within toxic heavy metal contaminated soil.

Baker and Brook (1989) defined metal hyperaccumulating plants as those, which contain more than 1000 milligrams per gram $(\mathrm{mg} / \mathrm{g})$ of cobalt, copper, chromium, lead, or nickel or $10,000 \mathrm{mg} / \mathrm{g}(1 \%)$ of manganese or zinc. According to the U.S. Department of Energy, efficient hyperaccumulators have the following traits: high accumulation rates (even if low contamination levels exist); ability to accumulate several metals; fast growth; high biomass production; and resistance to diseases and pests.

Heavy metal contaminated plants should be harvested from the contaminated site before the plants reach sexual maturity. Hypoaccumulation can occur between the plant and species of animals or insects that consume it. A plant that reaches sexual maturity has a greater risk of insect exposure during pollination. 
The traditional method of disposal of contaminated plants is incineration. Extraction of metals from the plant tissue is a new and innovative method of recycling heavy metal contaminated plants.

- Soil Amendments

A wide variety of soil amendments are used to increase and lower the availability of heavy metals in phytoremediation procedures. Phosphates such as apatite amendments have been successfully used to lower the bioavailabitity and increase the geochemical stability of metal contaminated soil (Laperche et al., 1997). Toxic heavy metals bind to soil particles, which reduce phosphates. Ma et al. (1993), studied in situ processes of lead $(\mathrm{Pb})$ immobilization in contaminated soil and wastes using apatite. Results indicate the effective removal of $\mathrm{Pb}$ from aqueous solution, exchange resins, and $\mathrm{Pb}$-contaminated soil material and suggests that apatite has the potential to immobilize $\mathrm{Pb}$ in situ in $\mathrm{Pb}$ contaminated soils and wastes.

Organic soil amendments will lower the availability of $\mathrm{Zn}$ and increase the availability of most other heavy metals. Solid organic matter and organic matter in solution will absorb metals. Organic soil amendments can ameliorate metal toxicity to plants by redistributing metals to less available fractions. The association of heavy metal with organic matter varies directly with soil pH (Shuman, 1999).

The distribution of metals is significantly influenced by soil $\mathrm{pH}$ and organic matter content (Zang et al. 1997; Tagwira et al. 1993). The up-take of many heavy metals can be increased by the reduction of $\mathrm{pH}$ within soil. Heavy metal bioavailability increases with the decrease of $\mathrm{pH}$. Decreasing $\mathrm{pH}$ will in turn increase the solubility of metals. 
Liang (1997) reported the high $\mathrm{pH}$ of the compost affected the solubility of the metal hydroxide and carbonates, and low $\mathrm{pH}$ values increase the solubility of heavy metals. The $\mathrm{pH}$ of soil can be a direct determinant of the type of association heavy metals have with organic materials. Lower soil $\mathrm{pH}$ levels with the addition of organic amendments will increase metal availability to plants. Organic amendments are used as an effect tool to reduce plant up-take if high soil $\mathrm{pH}$ levels are maintained.

High levels of soil $\mathrm{pH}$ can be maintained by liming the soil. Hydrated line is used with the addition of organic materials to effectively restrict heavy metal mobility within soil (Paff et. al., 1995).

Amendments such as compost and chelating agents are used to separate heavy metal from soil particles, which increases the metal's availability within soil. Chelates have been used in soils and nutrient solutions to increase the solubility of metal cations in plant growth media and are reported to have significant effects on metal accumulation in plants (Huang et al. 1997). The long-term effects of chelates within soil have been found to be detrimental to the environment. Chelating agents are more expensive than compost amendments and require careful management (Huang et al. 1997).

\section{- Compost}

Organic amendments such as compost shifts heavy metals to a more available form, if a high level of $\mathrm{pH}$ is maintained. Metals react with organic materials forming complexing bonds. Composting is a biological process in which microorganisms convert organic materials such as manure, leaves, paper, and food wastes into a soil-like material called compost (Rynk et.al, 1992). The addition of compost to decrease plant 
accumulation of heavy metals was chosen as an alternative to traditional soil amendments.

Shuman (1988) studied the effect of organic matter on the distribution of manganese $(\mathrm{Mn})$, copper $(\mathrm{Cu})$, Iron $(\mathrm{Fe})$, and Zinc $(\mathrm{Zn})$ in soil fractions. Increased additions of organic matter caused manganese and iron to move from the less soluble forms to more plant-available forms. The probable mechanism for this movement was a reduction of oxidation. The addition of fresh organic matter causes a flush of microbial activity, which adds complexing agents to the soil and affects the redox status. Results demonstrate that accumulated organic matter near the surface can increase plant availability of manganese and iron and possibly decrease availability of zinc by causing a redistribution of elements between soil fractions. A further study concluded that natural soil matter and organic material added to contaminated soil during remediation decreases Zn availability to plants (Shuman, 1999).

\section{- Bioavailabilty of Heavy Metals}

Toxic heavy metals bind to cell walls or the cell surface of soil. Soil amendments, such as compost, aid in the release of these bond metals. Humic and folvic acids present within compost increase the release of metals from contaminated soil. Humic acids are compounds which are composed of dark organic substances that are precipitated upon acidification of a basic extract from soil (Rynk, 1998). Humic and folvic acids are both fractions of humic substances or humus. Humus is a material comprised of many organic substances and represents a state during the decomposition of organic materials (Epstien, 1997). 
Simeoni et al., (1984) reported that the addition of a compost produced high yields of zinc ( $\mathrm{Zn}$ ) availability. $\mathrm{Zn}$ can be found in five major forms in soil: 1) in soil solution as ionic or organically complexed species; 2 ) on exchange sites of reactive soil components; 3) complexed with organic matter; 4) occluded in oxides and hydroxides of $\mathrm{Al}, \mathrm{Fe}$, and $\mathrm{Mn}$; and 5) entrapped in primary and secondary minerals (Iyengar et al. 1981). The amount of $\mathrm{Zn}$ forms varies considerably in soil. White (1957) studied the distribution of $\mathrm{Zn}$ in 14 Tennessee soils. Results indicated that 1 to $7 \%$ of the distribution of $\mathrm{Zn}$ was on exchange sites of clay minerals, 10 to $40 \%$ was held by organic matter or in lattice positions of clay minerals, 20 to $45 \%$ was held on lattice position of clay minerals, and 30 to $60 \%$ was associated with Fe-oxides. Shuman (1979) reported that 1 to $7 \%$ of the $\mathrm{Zn}$ in ten Georgia soils was in the bioavailable form and 12 to $20 \%$ were in the organic and noncystalline Fe-oxide forms.

The distribution and bioavailability of heavy metals vary, depending on the soil fraction. Iyengar et al. (1981) reported that water soluble, exchangeable, and absorbed fractions are readily available to plants; while primary and secondary soil minerals are relatively unavailable to plants.

The metal species present and their relative bioavailability within the soil is of greater importance than the total metal concentration in the environment that determines the overall physiological and toxic effects on biological systems (Bernhard et al., 1986; Hughes et al., 1989; Morrison et al., 1989). The efficiency of remediation processes is determined, in large part, by the redox potential and $\mathrm{pH}$. Redox potential is established by oxidation-reduction reactions in the environment. Oxidation-reduction is a reduction involving the transfer of electrons from one molecule to another. The redox potential is a 
measure of the tendency of a substance to donate or accept electrons respectively (Lim, 1998). Reducing conditions often result in metal precipitation; while oxidizing conditions promote the increased solubility of metals in a free ionic form. Oxidation conditions can decrease the $\mathrm{pH}$ within soil.

- Hyperaccumulating Plants

Hyperaccumulators are plants that can absorb high levels of contaminants with their roots and concentrate them either within their roots, shoots, and leaves (Watanabe, 1997). A variety of plant species is commonly used to remove heavy metal from soil. Brassica juncea (indian mustard) and Thlaspi rotundifolium (pennycress) are often used to remediate wet land areas (Blaylock et al., 1997). Thlaspi are known to efficiently accumulate zinc, lead, and cadmium. In addition, to zinc, lead, and cadmium, B. juncea has the ability to accumulate nickel. Alyssum (poplar) trees also have the ability to accumulate nickel. Crop species, such as Zea mays (corn) and Pisum sativum (pea) were successfully used to accumulate $\mathrm{Pb}$ (Huang et al., 1997). Ebbs et al. (1998) studied the effects of Avena sativa (oat) and Hordeum vulgare (barley) as hyperaccumulators in $\mathrm{Zn}$ contaminated soil. Rudbueckia hirta (black-eyed Susan), a perennial flower, accumulated significant amounts of $\mathrm{Cd}, \mathrm{Cu}, \mathrm{Pb}$, and $\mathrm{Zn}$ (Sawhney et al., 1994). Plants from many other families have been shown to remove cobalt, copper, chromium, manganese, and selenium from contaminated soil (Watanabe, 1997).

- Nodulation of White Clover in Metal Contaminated Soil

Biological fixation of atmospheric nitrogen can be estimated at 175 metric tons per year, or about $70 \%$ of all nitrogen fixed on the earth each year. The major contributor of nitrogen fixation comes from symbiotic systems, such as, Rhizobium (legumes). 
Leguminoseae plants (Rhizobium and Legume association) have been estimated to contribute to $50 \%$ of all nitrogen fixed on the earth (Food and Agriculture Organization of the United Nations, 1993).

Nitrogen fixation and nodulation are restricted when grown in heavy metal contaminated soil. El-Kenawy et. al., (1997) studied the effects of $\mathrm{Zn}$ and Cd have on the nodulation of white clover. The weight of shoots decreased with the increase of $\mathrm{Zn}$ contamination. Cadmium was more toxic to plant growth than $\mathrm{Zn}$. The process of nodulation was susceptible to the toxic effects of heavy metals.

Roots nodules generally grow best in the temperatures range of $25^{\circ}-30^{\circ} \mathrm{C}$, and in pH of six to seven (Vincent, 1970). Rhizobia bacteria resides within a healthy nodules. Root nodule bacteria are heterotrophic and able to utilize a wide variety of carbohydrates. Inoculation of rhizobia is applied to the white clover seedling during the initial planting. The infection process takes place within 48 hours of inoculation (Callaham, 1980). The growth and health of rhizobia are dependent on the availability of inorganic nitrogen.

- Sequential Extraction of Heavy Metal Contaminated Soil

The extractions of metal from soil involves multiple fractions of increase acidic strength. Sequential extraction procedures determine the degree in which metal are bond within soil particles. Soils that have metals that are readily available will release higher amounts of metal in earlier fractions. Several different sequential extraction procedures have been developed and are commonly used. Most procedure consists of water soluble, exchangeable, Fe, and Mn fractions. The solutions used within each procedure are quite different; however, the methods of extraction are similar. 
Tessier et. al. (1979) introduced a procedure involving chemical extraction for the partitioning of particulate trace metals into chemical forms likely to be released in solution under various environmental conditions. Mclaren, (1979) used two exchangeable fraction which consisted of $\mathrm{CaCl}_{2}$ and Hoac, respectively, with 24 hour agitation periods. Shuman, (1985) developed a extraction procedure to measure Zn. Amorphous iron oxide and crystalline iron oxide fraction were among the six fractions used. Berti, (1995) introduced a method that uses a combination of new and established techniques. Extracting solutions and their order were based on the fractioning several different elements and the use of several different soil types.

The differences between most sequential extraction procedures includes the choice of extraction solutions, the target fractions, the order in which the fractions are removed, the difference in soil to solution ratio, shaking times, and particle size of the sample (Berti et. al., 1995). The progression of new sequential extractions involved the development of more specific procedures for equally specific task. There is currently no standard sequential chemical extraction method. The technique of Tessier et. al. (1979) procedure is generally excepted because of its use by many others (Berti et. al. 1995). 


\section{CHAPTER 3}

\section{Materials \& Methods}

\section{Collection of the Contaminated Soil for this Study}

The contaminated soil sample was collected beneath a shelter overhang on the west side of a Harrison County owned playground. The playground was adjacent the Zinc Spelter Plant (source of contamination). The soil sample was collected from the top $30 \mathrm{~cm}$ of the A horizon within a one meter $(\mathrm{m})$ by three meter area. A total of 45.42 liters (1) of soil was stored in 18.93 liter rubber containers.

AgRecycle Inc., of Pittsburgh, Pennsylvania provided 45.42 liters of yard waste compost. The compost was stored in 18.93 liter rubber containers. The soil and compost were air dried and sieved with a three mm plastic sieve and transferred to 2-liter pots.

\section{Preparation of Test Pots for Growth Chamber}

A pot study was conducted, using the metal contaminated soil, to determine metal uptake patterns. Two-liter pots were used as sample containers. Eighteen sample pots were prepared by adding $2.27 \mathrm{~kg}$ of soil to each pot. Six pots acted as the control. Ten percent and $40 \%$ compost additions (by volume) were added to each of 6 sample pots. The soil and compost additions were thoroughly mixed.

In order to maintain field capacity, distilled deionized water (DDW) was added until the soil reached its maximum saturation point and then allowed to drain for 24 hours. Five hundred $\mathrm{ml}$ of DDW was added to the control, $550 \mathrm{ml}$ to $10 \%, 600 \mathrm{ml}$ was added to $40 \%$ compost addition, and $800 \mathrm{ml}$ of DDW was added to the potting soil. A 172.82 $\mathrm{g}$ sample was removed from each of the pots for $\mathrm{pH}$ analysis and placed within a 
$100 \mathrm{ml}$ sealed container. The weight of each pot was then recorded. An Omega Model E2000D Balance was used for all procedures requiring a known mass with this study. - Preparation of Seedlings for Test Pots

Wheat and clover seeds were germinated under germination lights in acid washed sand. The two plant species remained under the germination lights for ten days. After the ten-day period the plants were transferred to pots. Each plant was rinsed with DDW. Six wheat seedling or ten clover seedlings were transferred into each pot. The plants were placed in the center of each pot, approximately five mm apart.

- Treatment of Pot Samples

After the transplanting process was completed were placed into a growth chamber to assure constant temperature, humidity, and light. The temperature remained at $20^{\circ} \mathrm{C}$ and the humidity remained constant due to a three liter humidifying unit, which was placed within the growth chamber.

The lights were pre set for 14 hours of light and 10 hours of darkness. The sample containers were weighed every three days. One ml of DDW was added to each two liters sample container for every gram lost between each three-day period. The average water loss weight was determined for each two liters sample container after three weeks.

pH was tested twice per week using a Fisher Scientific Accumet Model 15 pH meter. Five grams of soil was removed from each sample containers. Ten ml of DDW was added to each of the five $\mathrm{ml}$ samples.

- Collection of Plant and Soil Samples Pots

The pots were removed from the growth chamber after seven weeks. The plants and roots were removed from each pot. A $50 \mathrm{ml}$ soil sample was collected from the 
rizosphere of the plants in each pot. An additional $50 \mathrm{ml}$ bulk sample was collected from an outermost area of the pot. Rhizosphere and bulk samples were stored in a refrigerator until further use. The plants and root systems were separated and rinsed with DDW. The lower six inches of the wheat plants were separated from the upper portion of the plants. The plants were transferred into aluminum dishes and placed in an oven for four days at $75^{\circ} \mathrm{C}$. The dried plant and root tissue was placed within one liter plastic bags and crushed.

- Sequential Extraction of Bulk and Residual Soil

One gram of bulk and rizosphere soil was placed into separate $15 \mathrm{ml}$ polycarbonate centrifuge tubes. An additional replication sample was prepared for every sample. A total of seventy-eight soil samples were prepared for sequential extraction procedures. Twelve $\mathrm{ml}$ of DDW was added to each centrifuge tube at room temperature. Water soluble, exchangeable, carbonate, Fe-Mn oxides, organic, and residual fractions were obtained using the procedure of Tessier et al. (1979).

Water Soluble. Soil sample extracted with $12 \mathrm{ml}$ of DDW and shaken vigorously for two hours.

Exchangeable. The residue form water soluble fraction was extracted with $12 \mathrm{ml}$ of $1 \mathrm{M} \mathrm{MgCl}_{2}$ ( $\left.\mathrm{pH} 7.0\right)$ with one hour of vigorous agitation.

Carbonate-Bound. The residue from exchange fraction was extracted with $12 \mathrm{ml}$ of $1 M \mathrm{NaOAc}$ (adjusted to $\mathrm{pH} 5.0$ with HOAc) with five hours of vigorous agitation.

$F e-M n$ Oxides-Bound. The residue from carbonate fraction was extracted with $0.04 M \mathrm{NH}_{2} \mathrm{OH} . \mathrm{HCl}$ in $25 \%$ (v/v) $\mathrm{HOAc}$ at $96^{\circ} \mathrm{C}$ with occasional agitation for six hours. 
Organic-Bound. The residue from Fe-Mn oxide fraction was extracted with $3 \mathrm{ml}$ of $0.02 \mathrm{MHNO}_{3}$ and five $\mathrm{ml}$ of $30 \% \mathrm{DDW}$ (adjusted to $\mathrm{pH} 2.0$ with $\mathrm{HNO}_{3}$ ). The mixture is heated within an agitating water bath at $85^{\circ} \mathrm{C}$ for two hrs, with occasional agitation. A second three $\mathrm{ml}$ aliquot of $30 \% \mathrm{H}_{2} \mathrm{O}_{2}\left(\mathrm{pH}\right.$ with $\mathrm{HNO}_{3}$ ) was added and the mixture heated $30 \% \mathrm{H}_{2} \mathrm{O}_{2}\left(\mathrm{pH} 2.0\right.$ with $\mathrm{HNO}_{3}$ ) was added and the mixture heated to $85^{\circ} \mathrm{C}$ for one hour with intermittent agitation. After cooling, five ml of $3.2 M \mathrm{HN}_{4} \mathrm{OAc}$ in $20 \%(\mathrm{v} / \mathrm{v}) \mathrm{HNO}_{3}$ is added and the samples diluted to $20 \mathrm{ml}$ and agitated continuously for 30 minutes.

Residual. The residue form organic fractions was digested using a $\mathrm{HF}, \mathrm{HCl}$, $\mathrm{HNO}_{3}$ dissolution procedure. After each successive extraction, separation was done with an IEC Model $\mathrm{K}$ Centrifuge at $12 \mathrm{~K} \mathrm{rpm}$ for $15 \mathrm{~min}$. The supernatants were removed and analyzed for $\mathrm{Cd}, \mathrm{Zn}$, and $\mathrm{Pb}$ with a Perkin Elmer Emission Spectrometer, Model P400. The residue was washed with $12 \mathrm{ml}$ of DDW followed by vigorous agitation. The residue was then centrifuged for $15 \mathrm{~min}$ and the supernatants were removed before the next extraction. An Eberbach horizontal shaker was used for all procedures involving vigorous agitation. One hundred microliters $(\mu \mathrm{l})$ of $\mathrm{HNO}_{3}$ was added to each sample.

- Microwave Digestion

The residual soil and dried plant and root materials were respectively sequentially extracted and digested using a CEM Model MDS-2000 microwave. Method SW 846-3051 was preformed for all residual soil samples, while the alfalfa method was used for all plant and root samples (Table 3.1).

All samples that were microwave digested required $0.5 \mathrm{~g}$ of the sample and $10 \mathrm{ml}$ of $\mathrm{HNO}_{3}$ into each vessel. Seventy-eight residual and 60 plant and root samples were prepared. The microwave was programmed as follows: 
Table 3.1 - Microwave procedures used for soil and plant material.

\begin{tabular}{|l|c|c|c|c|}
\hline METHOD & SW 846-3051 & \multicolumn{3}{|c|}{ ALFALFA } \\
\hline Stage & 1 & 1 & 2 & 3 \\
\hline$\%$ POWER & 100 & 100 & 100 & 100 \\
\hline PSI & 85 & 40 & 85 & 150 \\
\hline TIME & $10: 00$ & $6: 00$ & $6: 00$ & $10: 00$ \\
\hline TAP & $4: 30$ & $3: 00$ & $3: 00$ & $5: 00$ \\
\hline TEMPERATURE & 175 & 130 & 150 & 200 \\
\hline FAN SPEED & 100 & 100 & 100 & 100 \\
\hline
\end{tabular}

\section{- Perkin Elmer Emission Spectrometer}

Following the completion of the microwave digestion, the residual plant and root samples, bulk and rizosphere soil samples, and soil fractions were analyzed for $\mathrm{Cd}, \mathrm{Zn}$, and $\mathrm{Pb}$ using a Perkin Elmer Emission Spectrometer, Model P400. 


\section{CHAPTER 4}

\section{Results}

\section{Compost Amendment}

Compost data indicated that $\mathrm{Zn}, \mathrm{Cd}$ and $\mathrm{Pb}$ were present, but were, within national 503.13 standards (USEPA, 1993). The carbon:nitrogen ratio and soluble salt data were sufficiently within compost nutrient standards(Table 4.1). The $\mathrm{pH}$ was 8.15, which is above average for yard waste compost (Penn State, 1999).

Table 4.1 - The analysis of compost used in this study (Penn State, 1999).

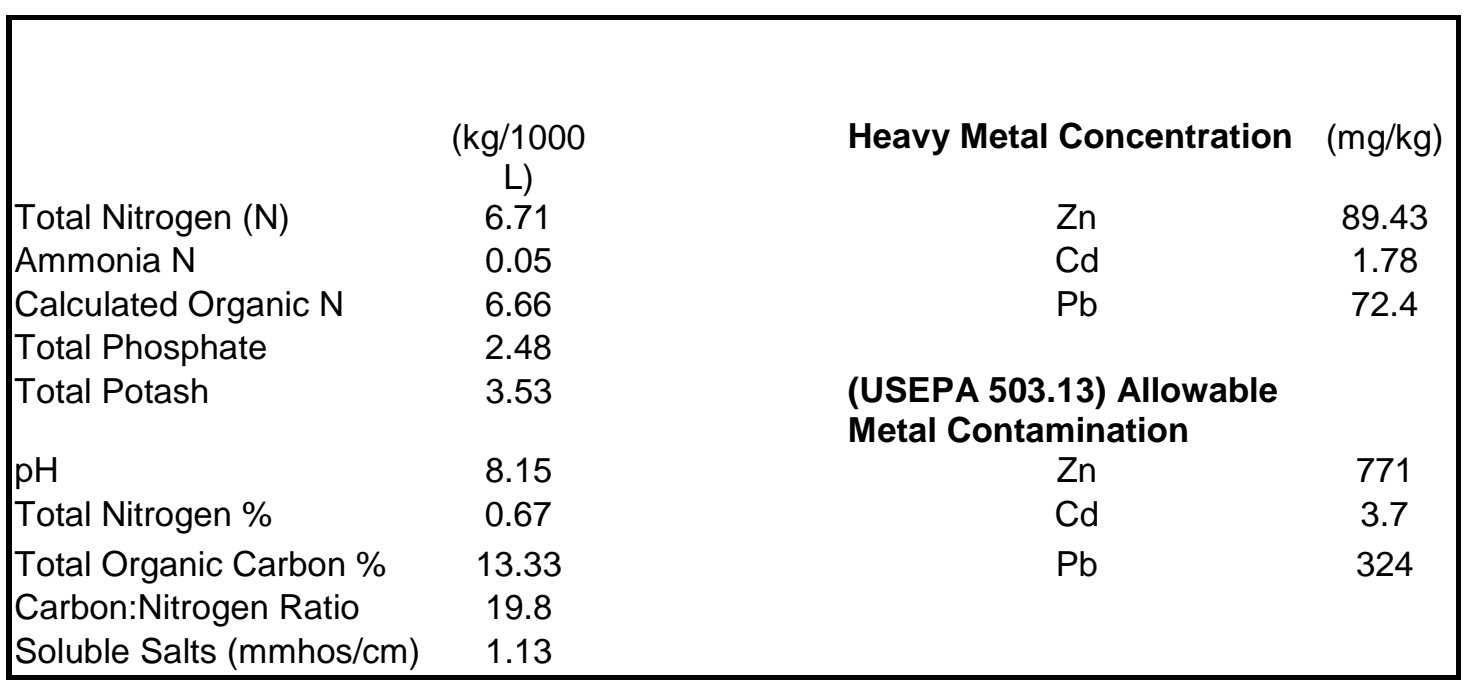

\section{$\underline{\text { Plant Health in Heavy Metal Contaminated Soil }}$}

A considerable increase in growth occurred in compost amended soils. The addition of compost increased the growth levels. A measurement of the total length revealed that $10 \%$ compost $(\mathrm{CM})$ wheat samples were $12 \%$ taller than control $(\mathrm{CO})$ wheat; while, $40 \% \mathrm{CM}$ wheat were $27 \%$ taller than $\mathrm{CO}$ wheat (Table 4.2 ). Visually, $10 \%$ $\mathrm{CM}$ and $40 \% \mathrm{CM}$ white clover and wheat samples had more vigorous roots and shoots than $\mathrm{CO}$ (Figure $4.1 \& 4.2$ ). 
Table 4.2 - The increases plant growth efficiency is due to the addition of compost.

\begin{tabular}{|l|l|r|r|r|r|}
\hline \multicolumn{2}{|c|}{} & \multicolumn{2}{|c|}{ Wheat } & \multicolumn{2}{c|}{ Clover } \\
\cline { 3 - 6 } \multicolumn{1}{|c|}{ Control } & Shoots & Roots & Shoots & Roots \\
\cline { 2 - 6 } & St Dev $(\mathrm{g})$ & 0.222 & 0.03 & 0.019 & 0.005 \\
\cline { 2 - 6 } & avg length $(\mathrm{cm})$ & 34.467 & NA & NA & NA \\
\cline { 2 - 6 } & St Dev & 1.595 & NA & NA & NA \\
\hline \multirow{4}{*}{$10 \%$ Compost } & dry wt. $(\mathrm{g})$ & 0.286 & 0.032 & 0.021 & 0.004 \\
\cline { 2 - 6 } & St Dev & 0.037 & 0.019 & 0.01 & 0.001 \\
\cline { 2 - 6 } & avg length $(\mathrm{cm})$ & 37.933 & NA & NA & NA \\
\cline { 2 - 6 } & St Dev & 1.457 & NA & NA & NA \\
\hline \multirow{4}{*}{ 40\% Compost } & dry wt. $(\mathrm{g})$ & 0.458 & 0.034 & 0.066 & 0.007 \\
\cline { 2 - 6 } & St Dev & 0.068 & 0.013 & 0.029 & 0.002 \\
\cline { 2 - 6 } & avg length $(\mathrm{cm})$ & 48.2 & NA & NA & NA \\
\cline { 2 - 6 } & St Dev & 2.696 & NA & NA & NA \\
\hline
\end{tabular}

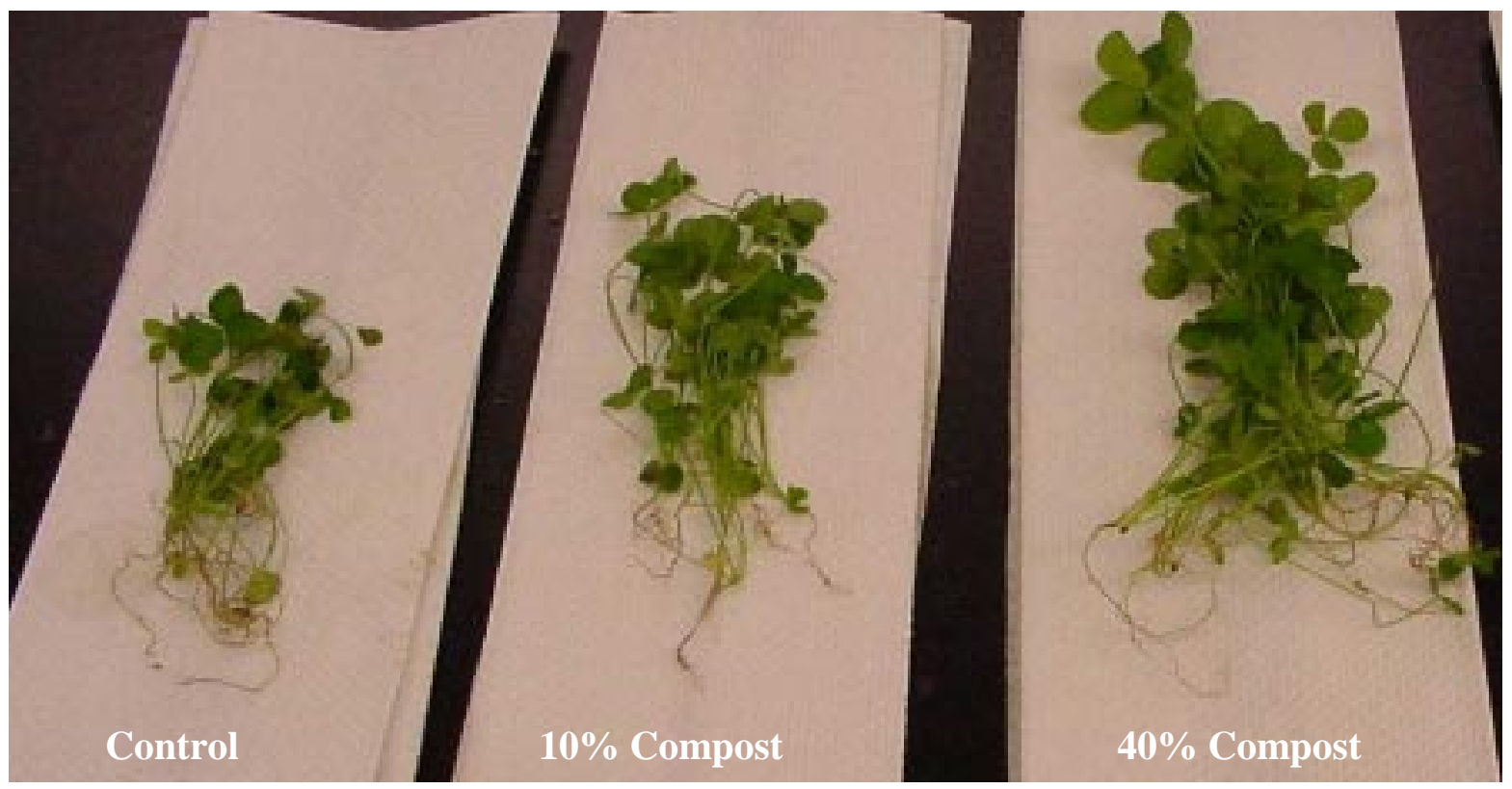

Figure 4.1 - White clover samples indicated improved health and growth with the increased addition of compost to heavy metal contaminated soil. 


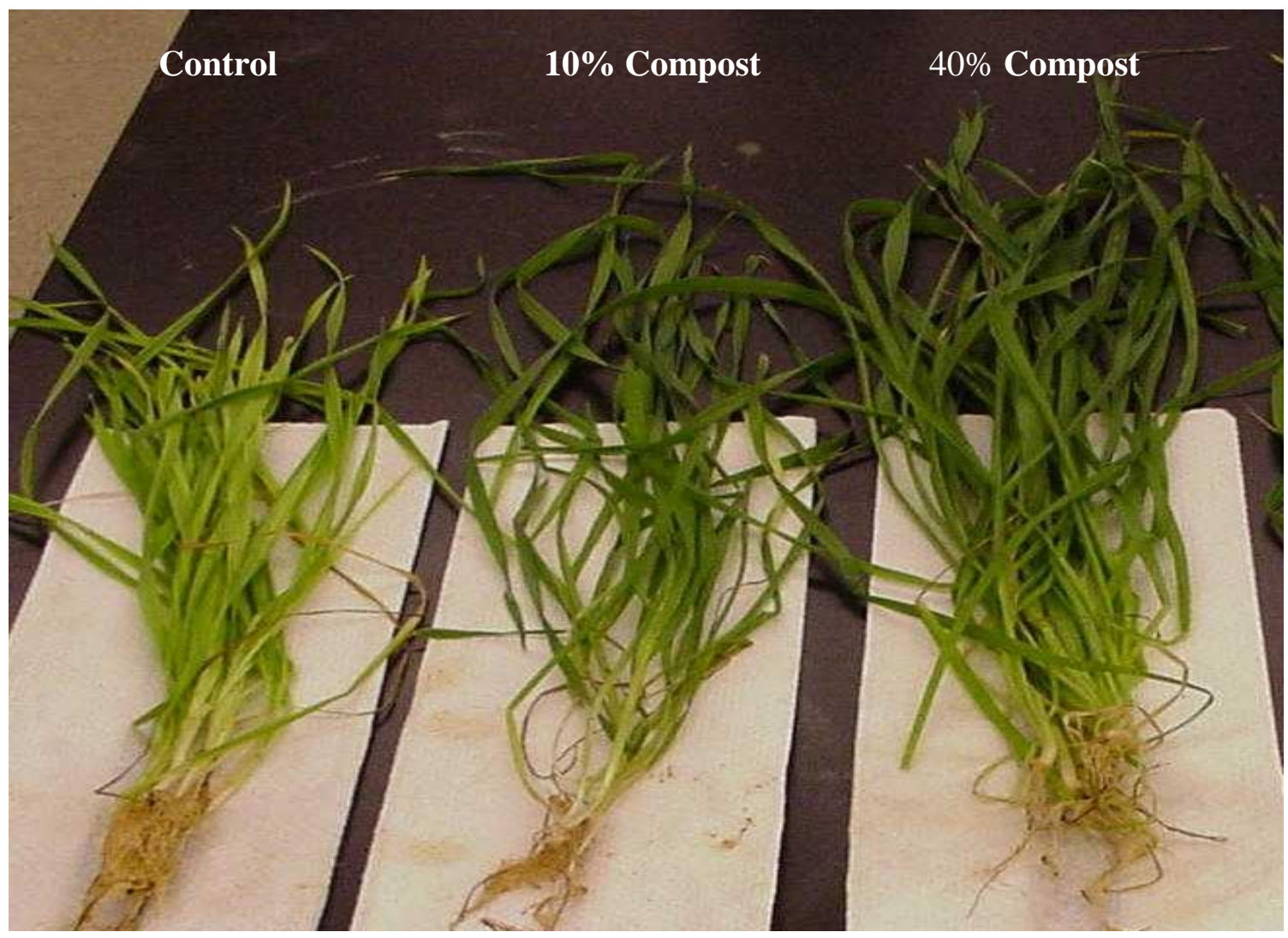

Figure 4.2 - The addition of compost to heavy metal contaminated soil improved root and shoot growth.

\section{$\underline{\text { Nodule Formation of White Clover }}$}

The addition of compost increased the health and nitrogen fixing ability of the white clover. Nodules of $\mathrm{CO}$ white clover plants were small, abnormally formed, with no signs of nitrogen fixation. $10 \% \mathrm{CM}$ showed improved nodule formation, health, and size; however, only a few nitrogen fixed nodules were present. The highest number of nitrogen fixing nodules were present in 40\% CM. A considerable increase of size and general health existed within nodules of 40\% CM (Figure 4.3). 


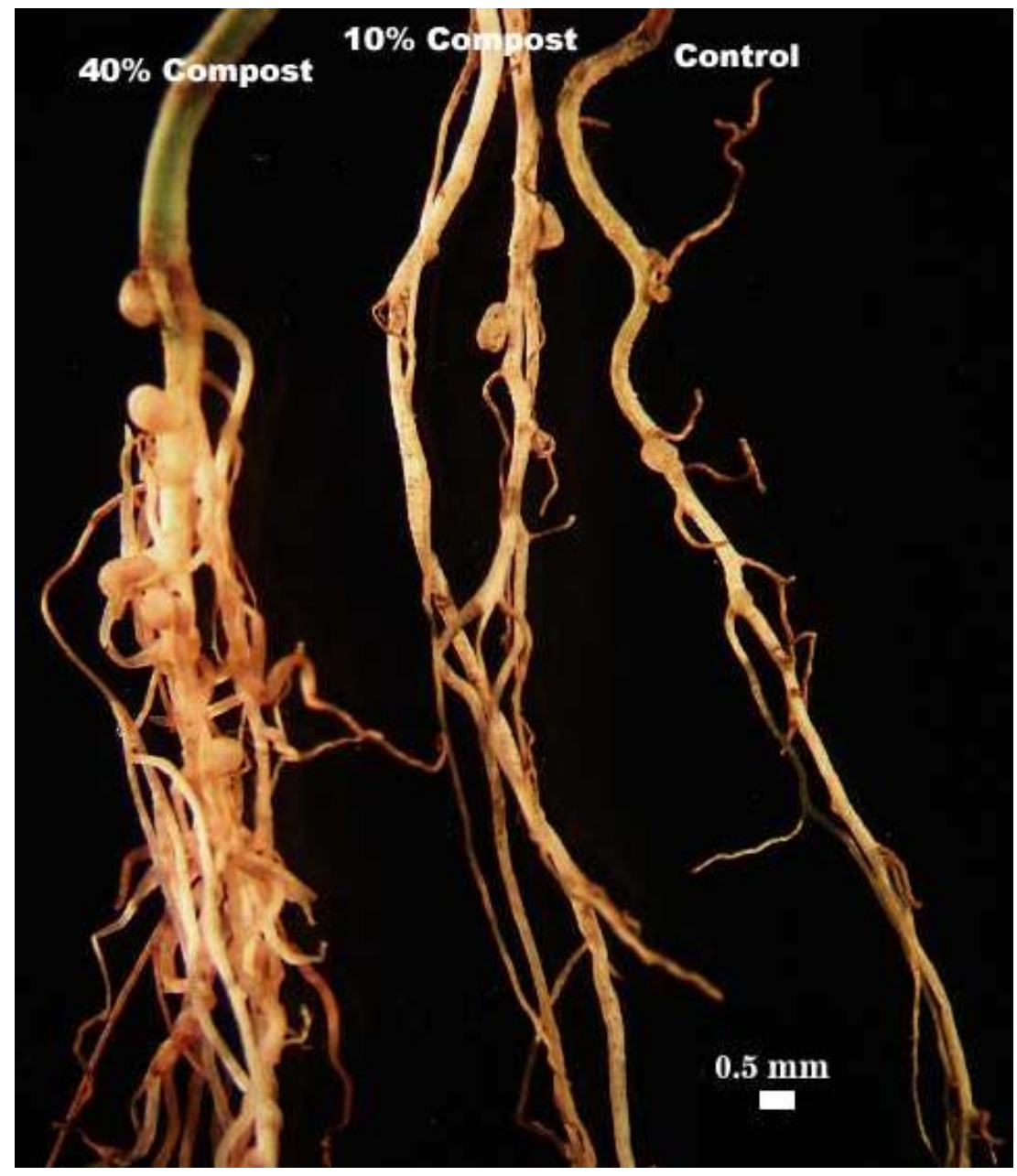

Figure 4.3 - The addition of compost increased nitrogen fixing ability and size of the nodules on white clover roots.

\section{$\mathrm{pH}$ of Heavy Metal Contaminated Soil}

The $\mathrm{pH}$ of all sample pots was determined over the seven-week period within the growth chamber (Figure 4.4). The mean of the pH CO soil samples were 5.65, while the $10 \% \mathrm{CM}$ was 5.96 , and the $40 \% \mathrm{CM}$ was 6.36 . 


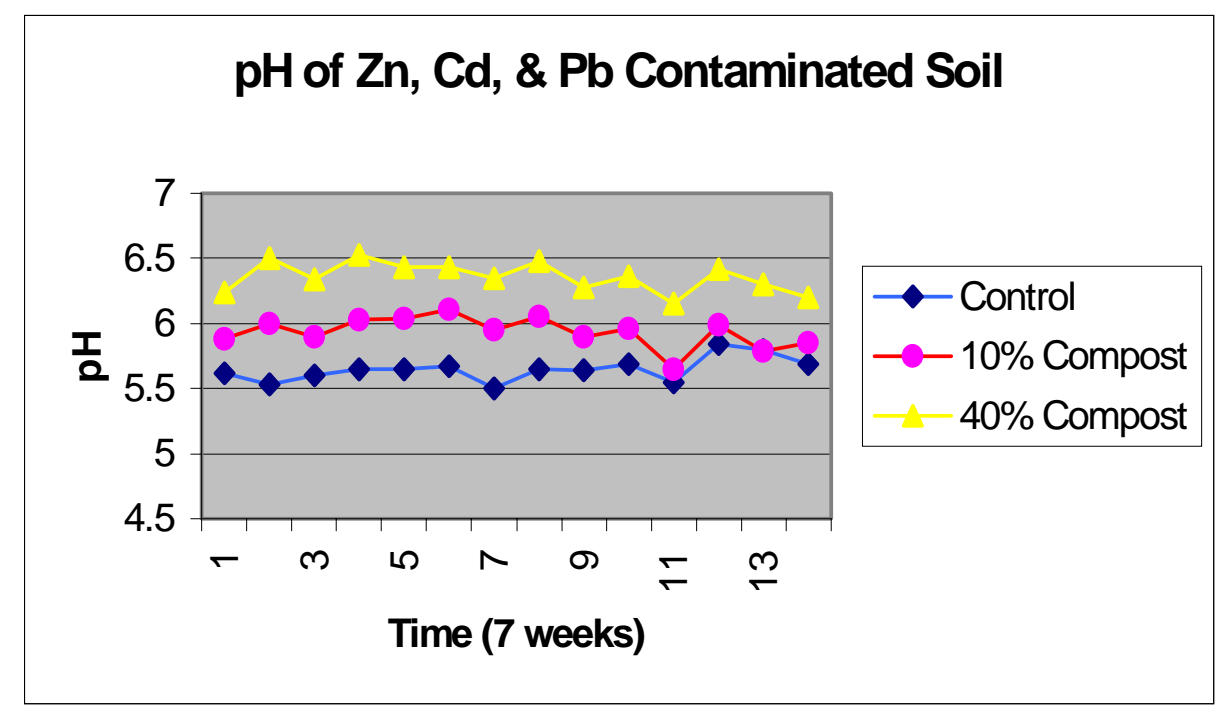

Figure 4.4 - High pH levels were maintained with the addition of compost in metal contaminated soils during the seven-week sample period.

\section{Heavy Metal Up-Take of Wheat and White Clover}

$\mathrm{CO}$ had the largest concentration of $\mathrm{Pb}$. Increased compost additions reduced the amount of $\mathrm{Pb}$ in the roots and shoots of white clover and wheat (Figure 4.5). The highest $\mathrm{Pb}$ concentrations were in roots of white clover. Data revealed that $925.83 \mathrm{mg} \mathrm{kg}^{-1} \mathrm{~Pb}$ was present in $\mathrm{CO}$ clover roots; while, $40 \% \mathrm{CM}$ clover roots had $331.27 \mathrm{mg} \mathrm{kg}^{-1} \mathrm{~Pb}$ (Table 4.3).

Zinc contamination was considerably higher than $\mathrm{Pb}$ or $\mathrm{Cd}$ concentrations. Wheat roots had the highest amount of $\mathrm{Zn}$ present (Figure 4.6). 10\% $\mathrm{CM}$ wheat roots contained $520.93 \mathrm{mg} \mathrm{kg}^{-1}$ less $\mathrm{Zn}$ than $40 \% \mathrm{CM}$. Clover had the ability to up-take larger concentrations of $\mathrm{Zn}$ than wheat. Levels of $1,014.26 \mathrm{mg} \mathrm{kg}^{-1}$ were found in $10 \% \mathrm{CM}$ clover shoots and $632.87 \mathrm{mg} \mathrm{kg}^{-1} \mathrm{Zn}$ was present in $10 \% \mathrm{CM}$ wheat shoots (Table 4.3). 
Data indicated that CO, $10 \% \mathrm{CM}$, and $40 \% \mathrm{CM}$ wheat $\mathrm{Zn}$ in lower or upper shoot portions. With the exception of $\mathrm{Zn}$ shoots, compost additions resulted in a reduction of ability to up-take $\mathrm{Zn}$ in both wheat and clover plants.

Compost addition reduced the up-take of $\mathrm{Cd}$ in of wheat and clover (Figure 4.7). Cadmium levels were lower than all other heavy metals analyzed. 10\% CM wheat roots and lower shoots contained less $\mathrm{Cd}$ than $40 \% \mathrm{CM}$ wheat roots and lower shoots. Compost addition had a more significant effect in reducing root up-take than shoots. $10 \% \mathrm{CM}$ additions reduced $\mathrm{Pb}$ levels in wheat roots by $96.24 \mathrm{mg} \mathrm{kg}^{-1}$; while, reduction in wheat shoots were $19.33 \mathrm{mg} \mathrm{kg}^{-1}$ (Table 4.3).

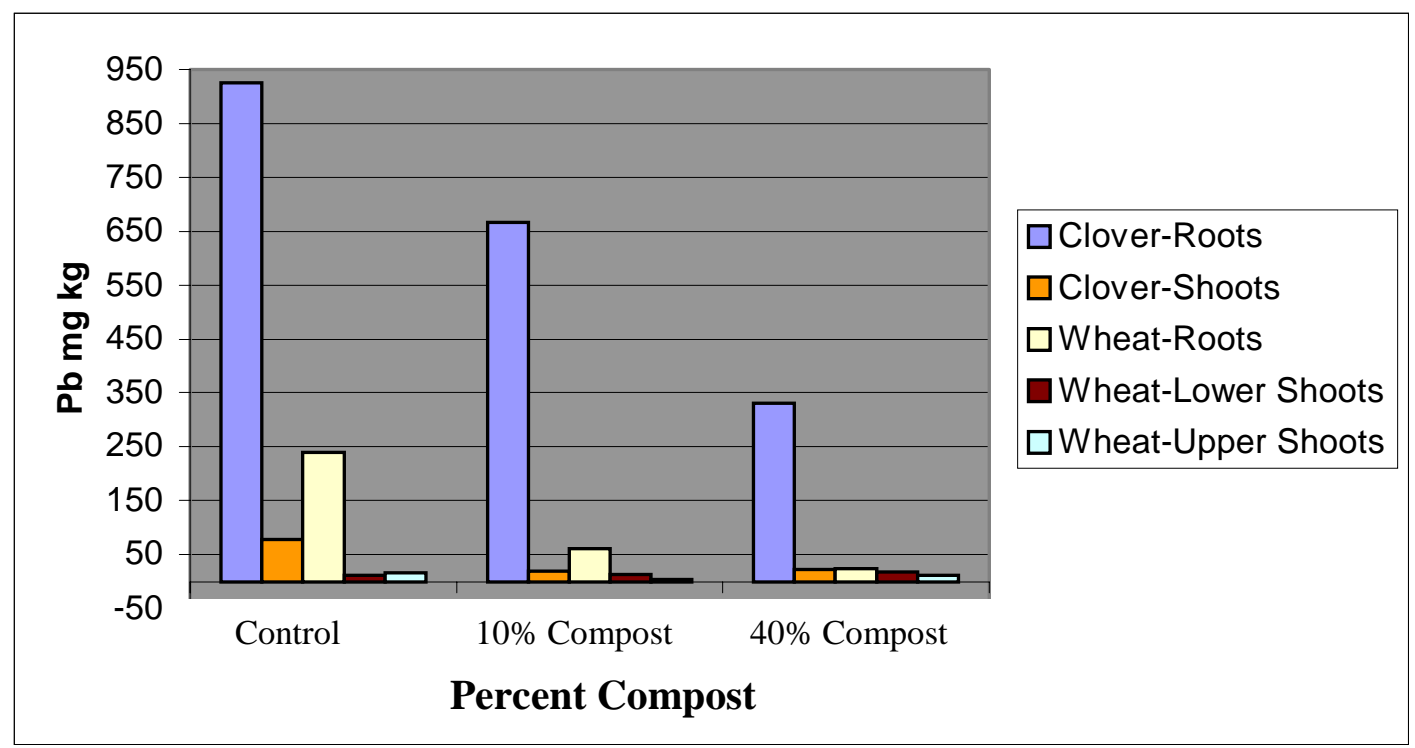

Figure 4.5 - A reduction of $\mathrm{Pb}$ within the plant material of white clover and wheat occurred with the addition of compost. 


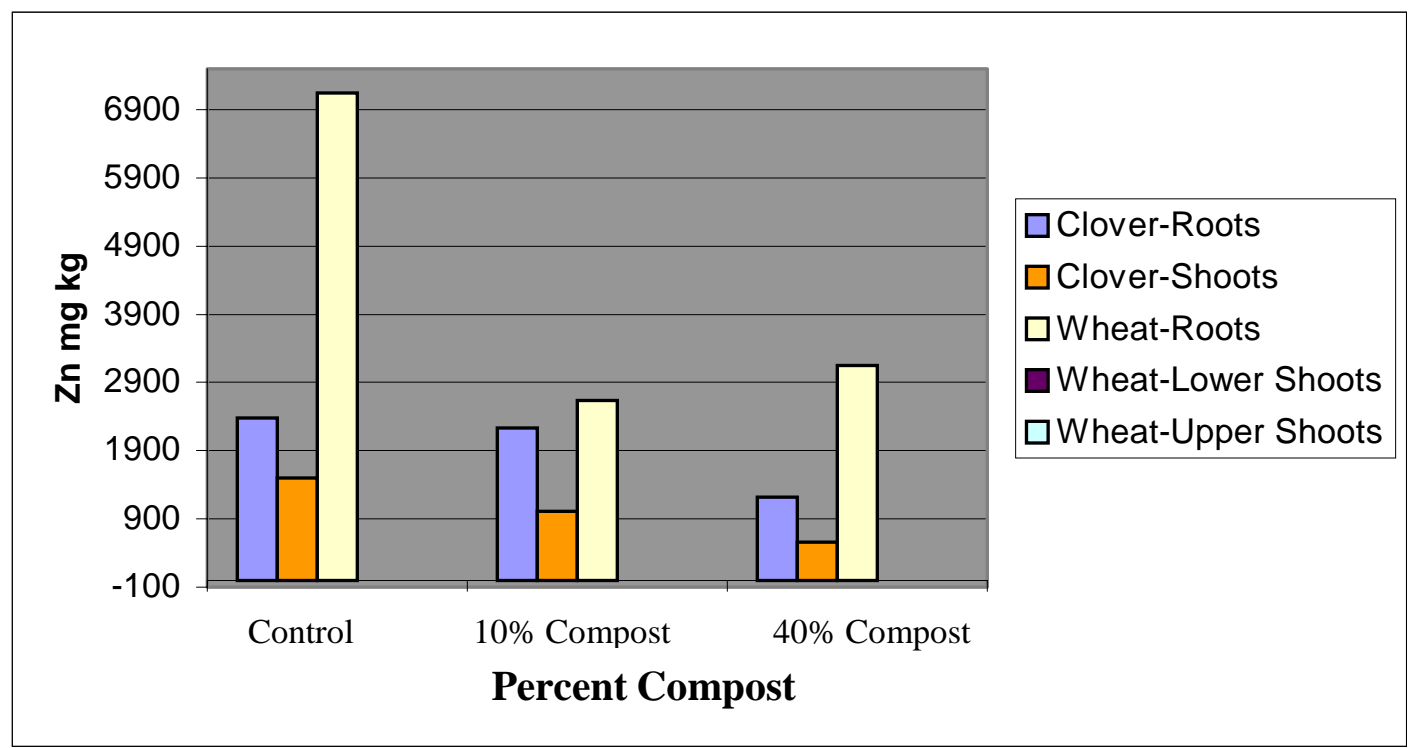

Figure 4.6 - A reduction of $\mathrm{Zn}$ within the plant material of white clover and wheat occurred with the addition of compost.

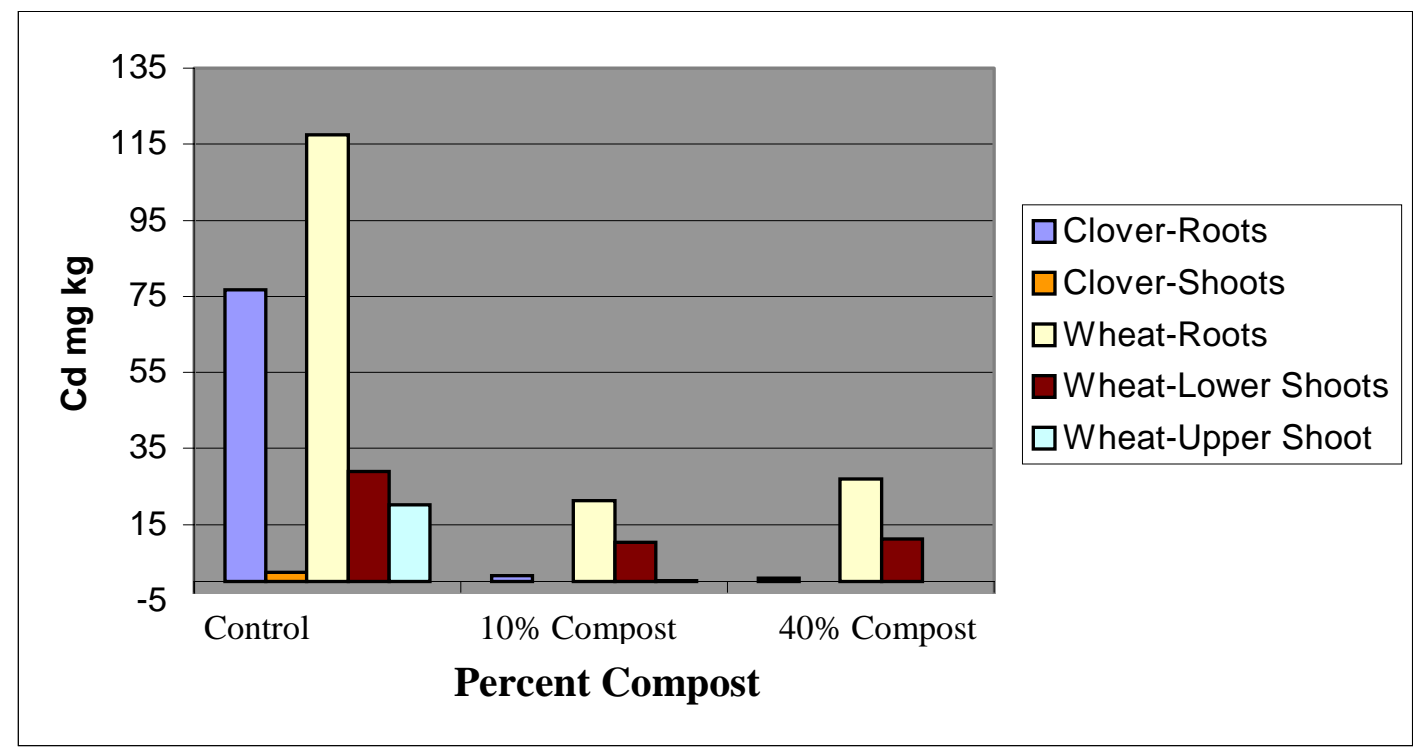

Figure 4.7 - A reduction of Cd within the plant material of white clover and wheat occurred with the addition of compost. 
Table 4.3 - Wheat has the ability to up-take a higher concentration of heavy metals than white clover.

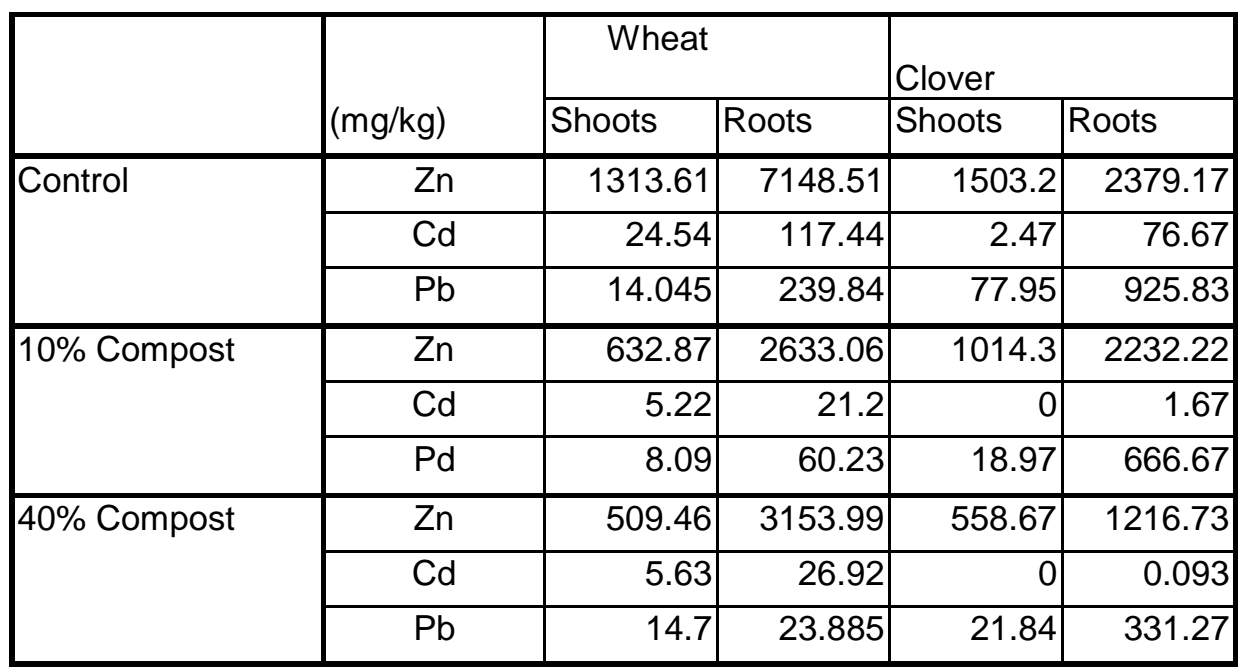

\section{$\underline{\text { Sequential Extraction of Heavy Metal Contaminated Soil }}$}

No substantial differences or patterns were present between bulk and rhizosphere soil samples.

\section{- Zn - Fe\&Mn Fraction}

The Fe\&Mn fraction had a gradual decline in the amount of $\mathrm{Zn}$ released with the increased addition of compost. Clover-bulk sample released $978.88 \mathrm{mg} \mathrm{kg}^{-1}$, however, the average amount of $\mathrm{Zn}$ released was $904.66 \mathrm{mg} \mathrm{kg}^{-1}$. Overall, $900.61 \mathrm{mg} \mathrm{kg}^{-1}$ of $\mathrm{Zn}$ were released in 40\% CM white clover and wheat Fe\&Mn fractions. Data indicated that, on average, the largest amount of $\mathrm{Zn}$ was released in $\mathrm{CO}$ samples of both white clover and wheat soils (Figure 4.8). 


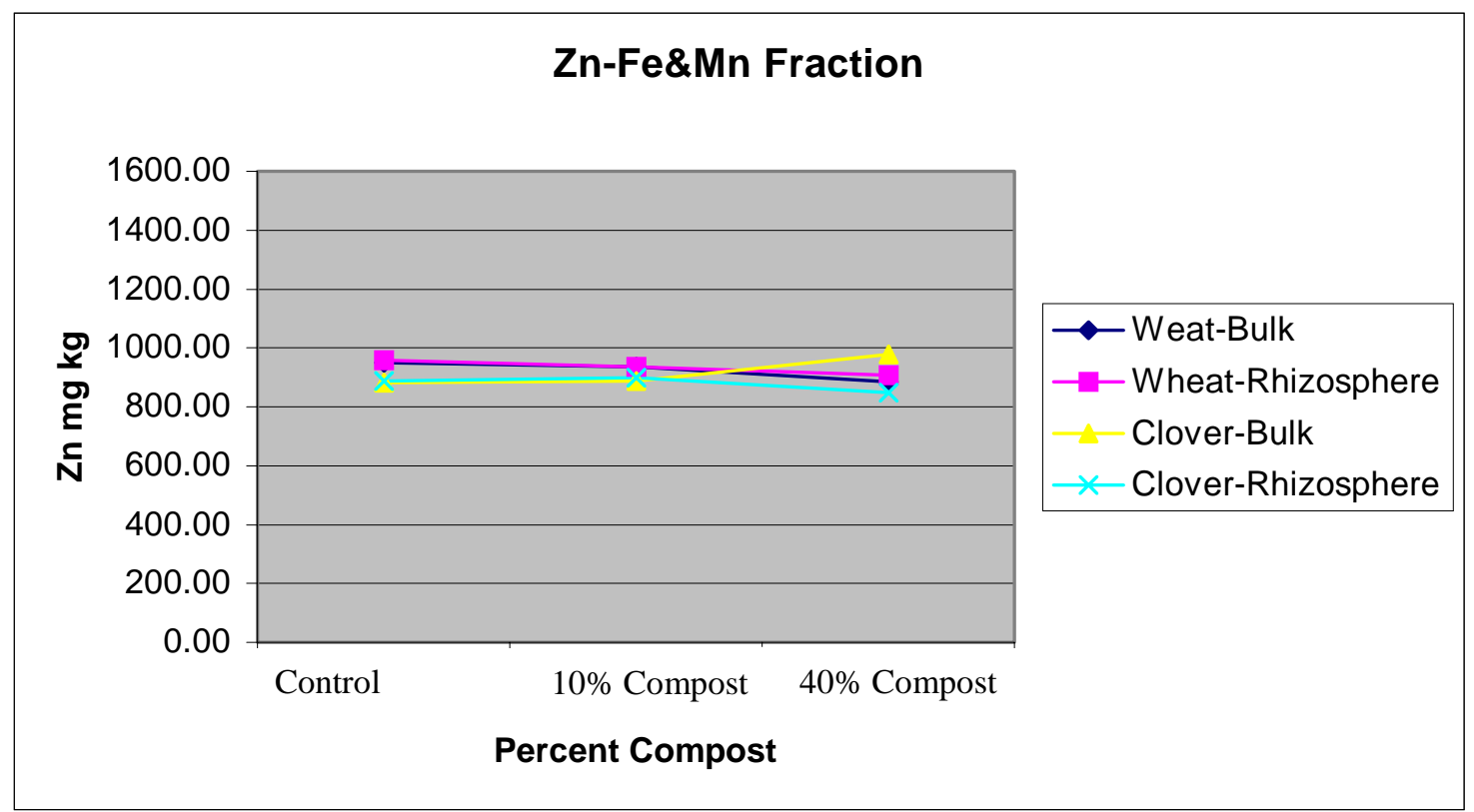

Figure 4.8 - The $\mathrm{Zn}$ analysis of the Fe\&Mn fraction showed a decrease in soils from $40 \% \mathrm{CM}$.

- $\mathrm{Pb}$ - Carbonate Fraction

The dramatic release of $\mathrm{Pb}$ was present from $\mathrm{CO}$ to $10 \% \mathrm{CM}$ in wheat soils. Ten percent $\mathrm{CM}$ wheat rhizosphere had lower levels of $\mathrm{Pb}$ than all other soil sample types.

The amount of $\mathrm{Pb}$ within $10 \% \mathrm{CM}$ wheat rhizosphere was $57.85 \mathrm{mg} \mathrm{kg}^{-1}$. The average $\mathrm{Pb}$ release of $10 \% \mathrm{CM}$ wheat and white clover was 6.41 lower than $40 \% \mathrm{CM}$ samples (Figure 4.9). 


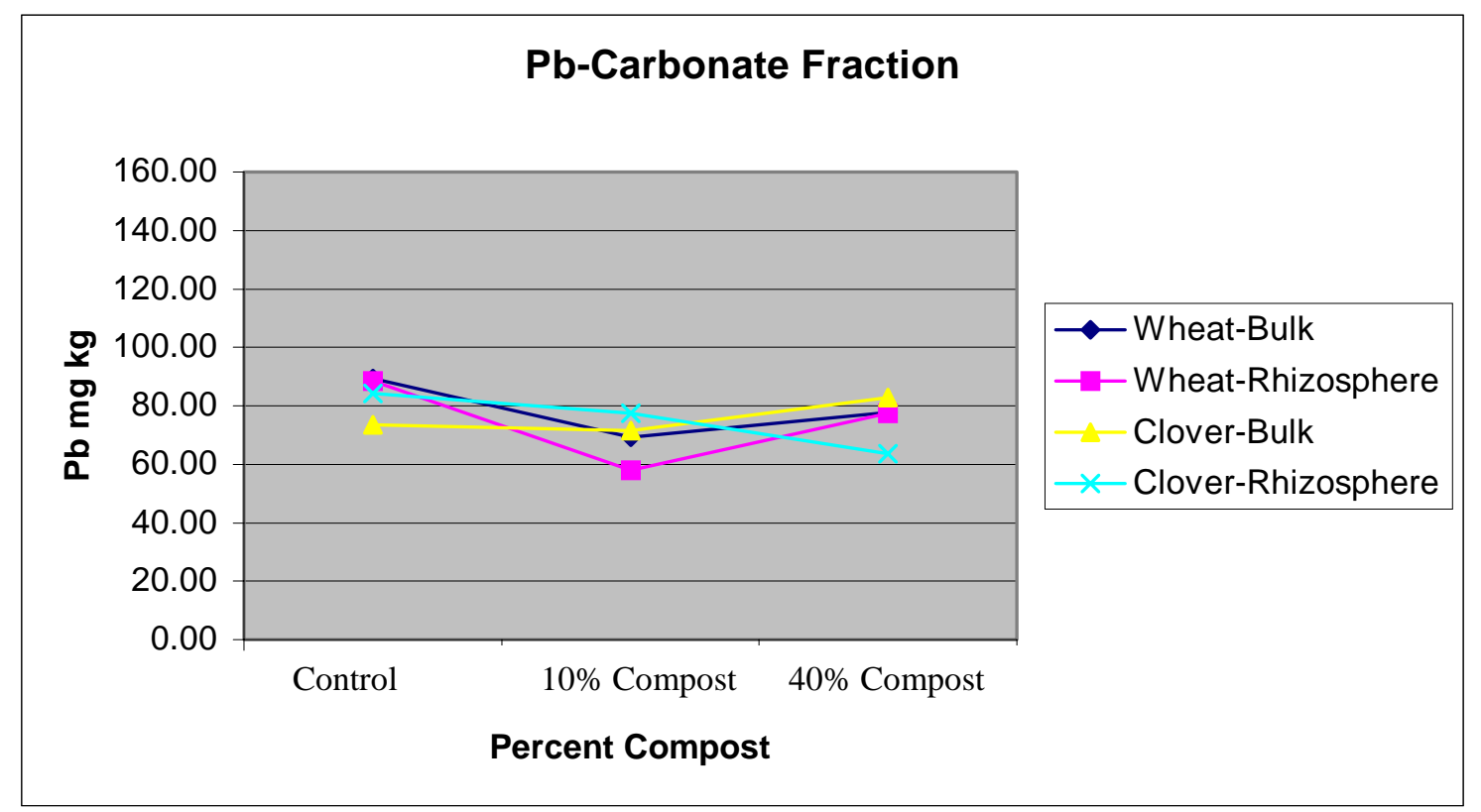

Figure 4.9 - Data revealed that $\mathrm{Pb}$ analysis of the carbonate fractions from $10 \%$ $\mathrm{CM}$ and $40 \% \mathrm{CM}$ white clover and wheat samples were less available than $\mathrm{CO}$ fractions. 


\section{CHAPTER 5}

\section{Discussion}

The addition of compost increased the total length of white clover and wheat. The increased growth of the plants was due to several changes that occur within low $\mathrm{pH}$, clayey soils when compost is applied. The optimum $\mathrm{pH}$ of wheat and clover is six to seven. Compost raised $\mathrm{pH}$ levels into the optimum range. Soil structure and nutrient supplies were elevated by the compost additions. Compost also provided an increase in porosity, water holding capabilities, and aeration of the soil.

However, the addition of compost drastically reduced the amounts of Zn, $\mathrm{Cd}$, and $\mathrm{Pb}$ up-take in both wheat and white clover. The average length of Control $(\mathrm{CO})$ wheat plants were $27 \%$ smaller than $40 \%$ compost (CM); yet, the control still had the ability to up-take $28.02 \%$ more $\mathrm{Pb}, 37.17 \% \mathrm{Zn}$, and a $247 \%$ increase of $\mathrm{Cd}$ than the healthier 40\% CM clover. Compost increased mean pH levels from 5.65 in $\mathrm{CO}$ to 6.36 in $40 \% \mathrm{CM}$. Heavy metals bind to the surfaces of soil particles under high $\mathrm{pH}$ conditions. The binding process resulted in a reduction of metal availability to wheat and white clover.

Plants are known to store higher amounts of heavy metals within their shoots, foliage, and roots; however, concentration of heavy metals in the roots of clover and wheat were much higher than their shoots. This disproportional metal concentrations within the roots may be due to the plants not to reaching maturity.

Heavy metals in soils are found in many chemical forms of varying degrees of availability. Fractions containing high levels of heavy metals indicate the physicochemical form that persists. The majority of $\mathrm{Zn}, \mathrm{Cd}$, and $\mathrm{Pd}$ was released from the 
soil in the carbonate and Fe-Mn Oxide fractions. Metals were moderately bound within the soil. Besides the established threat of plant up-take, the potential of leaching, ingestion, and assimilation in other organisms was present.

Nodule formation of white clover was adversely affected by heavy metal contaminants. Nodule health and nitrogen fixation are indicators of a sufficient supply of nutrients. Compost additions decrease the ill effects that metals can afflict upon the formation of nodules. $40 \% \mathrm{CM}$ provided white clover with an ample nitrogen source and high $\mathrm{pH}$ that resulted in healthy nitrogen fixed nodules.

\section{$\underline{\text { Conclusion }}$}

Heavy metal contaminated sites should not be taken lightly. Heavy metals can causes birth defects, mental retardation, cancer, and many other equally afflicting conditions. Application such as organic soil amendments can aid in reducing the risk of heavy metal contamination. Techniques introduced in this study may contribute to the efforts of eliminating heavy metal contamination as a threat to animals, invertebrates, and plant species. Applications of the present study were intended to be used in field condition to reduce the availability of $\mathrm{Zn}, \mathrm{Cd}$, and $\mathrm{Pd}$ within a clayey, low $\mathrm{pH}$ soil. 


\section{Bibliography}

Baker, A.J.M., and Brooks, A.J. (1989) Terrestial higher plants which hyperaccumulate metallic elements-a review of their distribution, ecology, and phytochemistry. Biorecovery. 1, 81-126.

Bernhard, M., Brinkman, F.E., and Sadler, P.J. (1986) The importance of chemical speciation on environmental processes. Springer-Verlag. Berlin.

Berti, W.R., Cunnimghan, S.D., and Jacods, L.W. (1995) Sequential chemical extraction of trace elements: development and use in remediating contaminated soils. Conference of Biochemistry of Trace Elements. Paris, France.

Blaylock, M.J., Salt, D.E., Dushenkov, S., Zarkharova, O., Gussman, C., Kapulnik, Y., Ensley, B.D., and Raskin, I. (1997) Enhanced accumulation of $\mathrm{Pb}$ in indian mustard by soil-applied chelating agents. Environmental Science Technology. 31, 860-865.

Callaham, D.A. and Torrey, J.G. (1980) The structural basis for infection of root hairs of Trifolium repens by Rhizobium. Canadian Journal of Botany. 59, 1647-1664.

Cunningham, S.D., Krueger, E.L., Anderson, T.A., and Coats, J.R. (1997) In phytoremediation of soil and water contaminants. American Chemical Society. Washington, D.C.

Ebbs, S.D., and Kochian, L.V. (1998) Phytoextraction of zinc by oat (Avena sativa), barley (Hordeum vulgare), and indian mustard (Brassica junea). Environmental Science Technology. 32, 802-806.

El-Kenawy, Z.A., Angle, J.S., Gewaily, E.M., El-Wafai, N.A., van Berkum, P. (1997) Journal of Agronomy. 89, 875-880.

Epstein, E. (1997) The science of composting. Technomic Publishing. Lancaster, PA.

Food and Agriculture Organization of the United Nations. (1993) Technical handbook on symbiotic nitrogen fixation: legume/Rhizobium. United Nations. Rome, Italy.

Forcella, Domenic. (1989) The role of waste minimization. National Governors' Association, Washington, D.C.

Huang, J.W., Jianjun, C., William, B.R., and Cunningham, S.D. (1997) Phytoremediation of lead-contaminated soil: role of synthetic chelates in lead phytoextraction. Environmental Science Technology. 31, 800-805.

Hughes, M.N., and Poole, R.K. (1989) Metals and micro-organismd. Chapman and Hall. New York. 
Iyengar, S.S., Martens, D.C., Miller, W.P. (1981) Distribution and plant availability of soil zinc fractions. Soil Science Society of America. 45, 735-739.

Laperche, V., Logan, T.J., Gaddam, P., and Traina, S.J. (1997) Effect of apatite amandments on plant uptake of lead from contaminated soil. Environmental Science Technology. 31, 2745-2753.

Lim, D. Microbiology, second edition. McGraw-Hill. Boston, MA. 647.

Ma, Q.Y., Traina, S.J., and Logan, T.J. (1993) In situ lead immobilization by apatite. Environmental Science Technology. 27, 1803-1810.

Mclaren, R.G. and Crawford, D.V. (1973) The fractions of copper in soils. Journal of Soil Science. 24, 172-181.

Morrison, G.M., Batley, G.E., and Florence, T.M., (1989) Metal speciation and toxicity. Chemistry in Britian. 8, 791-795.

Paff, S.W. and Bosilovich, B.E. (1995) Use of lead reclamation in secondary lead smelters for the remediation of lead contaminated sites. Journal of Hazardous Materials. 40, 139-164.

Penn State University Agriculture Analytical Services Laboratory. (1999) University Park, PA.

Qiao, L. and Ho, G. (1997) The effects of clay amendments on composting of digested sludge. Journal of Water Resources. 31, 1056-1064.

Roane, T.M., Pepper, I.L., and Miller, R.M. (1997) Microbial remediation of metals. Remediation: Principles and Applications. Cambridge University Press, United Kingdom. 312-340.

Rynk, R. (1989) Composting as a dairy manure technique. Dairy Manure Management. 31, 140-146.

Sawhney, B.L., Bugbee, G.J., and Stilwell, D.E. (1994) Leachability of heavy metal from growth media containing source-seperated municipal solid waste compost. Journal of Environmental Quality. 23, 718-722.

Scott, J.A. and Palmer, S.J. (1981) Cadmium bio-sorption by bacterial exopolysaccharide. Biotechnology Letters. 10, 21-24.

Shaw, D.J. (1995) Microbes safely, effectively bioremediate oil field pits. Oil and Gas Journal. January 85-88.

Shuman, L.M. (1979) Zinc, manganese and copper in soil fractions. Soil Science. 127, 10-17. 
Shuman, L.M. (1985) Fraction for soil microelements. Soil Science. 140, 11-22.

Shuman, L.M. (1998) Effect of organic matter on the distribution of manganese, copper, iron, and zinc in soil fractions. Soil Science. 146, 192-198.

Shuman, L.M. (1999) Organic waste amendments effect on zinc fractions of two soils. Journal of Environantal Quality. 128, 1442-1447.

Simeoni, L.A., Barbarick, K.A., and Sabey, B.R. (1984) Effect of small-scale sludge on heavy metal availability to plants. Journal of Environmental Quality. 13, 264-268.

Tagwira, F., Piha, M., and Mugwira, L. (1993) Zinc distribution in cotton using lime or mushroom compost. Soil Science \& Plant Analysis. 24, 841-861.

Tessier, A., Campbell, P.G.C., Bisson, M. (1979) Sequential extraction procedure for the speciation of particulate trace metals. Analytical Chemistry. 51, 844-851.

United States Environmental Protection Agency. (1993) Method 503.13. Federal Register. Washington, D.C.

Watanabe, M.E. (1997) Phytoremediation of the brink of commercialization. Environmental Science \& Technology. 31, 182-186.

West Virginia Department of Environmental Protection (1997) Sampling plan of zinc spelter plant; Spelter, West Virginia. 1-3.

White, M.L. (1957) The occurrence of zinc in soil. Economical Geology. 52, 645-651.

Vincent, J.M. (1970) Nitrogen Fixation is Legumes. Academic Press. Sydney, Australia. $5-15$.

Zhang, M., Alva, A.K., Li, Y.C., and Calvert, C.V., (1997) Fractionation of iron, manganese, aluminum, and phosphate in selected soils under citrus production. Journal of Soil Science Society of America. 61, 794-801. 


\section{Appendix}

Table - The total amount of $\mathrm{Zn}, \mathrm{Cd}$, and $\mathrm{Pb}$ loss that occurred in the soil.

\begin{tabular}{|l|c|r|r|r|r|}
\hline & & \multicolumn{2}{|c|}{ Wheat } & \multicolumn{2}{c|}{ Clover } \\
\cline { 2 - 6 } & $(\mathrm{mg} / \mathrm{kg})$ & Shoots & Roots & Shoots & Roots \\
\hline Control & $\mathrm{Zn}$ & 291.621 & 212.075 & 28.06 & 1.116 \\
\cline { 2 - 6 } & $\mathrm{Cd}$ & 5.448 & 3.484 & 0.046 & 0.358 \\
\cline { 2 - 6 } & $\mathrm{Pb}$ & 3.118 & 7.115 & 1.455 & 4.321 \\
\hline \multirow{4}{*}{ 40\% Compost } & $\mathrm{Zn}$ & 181.001 & 85.135 & 21.638 & 8.186 \\
\cline { 2 - 6 } & $\mathrm{Cd}$ & 1.493 & 0.685 & 0 & 0.006 \\
\cline { 2 - 6 } & $\mathrm{Pd}$ & 2.314 & 1.947 & 0.407 & 2.445 \\
\hline & $\mathrm{Zn}$ & 233.331 & 106.185 & 36.872 & 8.112 \\
\cline { 2 - 6 } & $\mathrm{Cd}$ & 2.579 & 0.906 & 0 & 0 \\
\cline { 2 - 6 } & $\mathrm{Pb}$ & 6.733 & 0.804 & 1.441 & 2.209 \\
\hline
\end{tabular}




\section{VITA}

NAME:

HOMETOWN:

DATE OF BIRTH:

PRIMARY EDUCTION

SECONDARY

PROFESSIONAL

WORK EXPERIENCE

\section{JASON THOMAS MORRISON}

Sutton, WV

June 30, 1976

Sutton Middle School, Sutton, WV

1986 to 1990

Braxton County High School, Flatwoods, WV

1990 to 1994

Bachelors of Science in Agriculture with a major in

Environmental Protection and a Minor in

Environmental Geography

1994 to 1998

Master of Science in Agriculture and Environmental

Technology

1999 to 2000

Graduate Research Assistant, West Virginia

University, 